\title{
Improved ways to screen for patients with Fabry disease, involving optometry in a multidisciplinary approach
}

\section{BY LANGIS MICHAUD \& CHRISTIANE AURAY-BLAIS}

\section{Introduction}

\begin{abstract}
lthough Fabry disease has Abeen known for more than a century (1898), this lysosomal storage disorder remains poorly recognized. With a prevalence of $1 / 40,000$ to 1/117,000 live male births, ${ }^{1}$ Fabry is considered one of 7,000 known rare diseases that exist in the US and reported. However, this number of patients seems to be underestimated. ${ }^{3}$
\end{abstract}

Many heterozygous subjects are affected without being diagnosed, no one seeing the globality of their symptoms. These are quite variable and unspecific, often leading to confusion with rheumatoid diseases or chronic inflammatory conditions. ${ }^{4}$ In some cases, the condition remains subclinical or is not characteristic of the full spectrum of the disease. A typical patient's odyssey means multiple visits to more than ten different medical specialists before he or she achieves a confirmatory
Langis Michaud, OD, MSc, FAAO (Dipl)

Associate Professor, École d'optométrieUniversité de Montréal

Christiane Auray-Blais, LLM, PhD

Service of Genetics, Department of Pediatrics Faculty of Medicine and Health Sciences Université de Sherbrooke

Disclosure: Author has received research grants and speaker fees from Genzyme Canada.

\section{RÉSUMÉ}

\section{Objet :}

La maladie de Fabry est considérée comme une maladie rare, de par sa prévalence. Cependant, ceci cache une réalité clinique toute autre en raison du nombre de cas non dépistés. Cet article vise à démontrer comment les optométristes, via un simple examen à la lampe à fente, peuvent aider à améliorer le dépistage des patients atteints, et ce, dans une perspective multi-disciplinaire.

\section{Méthode :}

Un modèle de dépistage a été instauré, en se basant sur l'éducation continue des optométristes. Les patients suspects de Fabry sont référés à l'École d'optométrie de l'Université de Montréal pour des tests supplémentaires. Dans le cas où I'histoire de cas et/ou les signes cliniques sont caractéristiques de la maladie de Fabry, un test urinaire est demandé, visant lidentification de biomarqueurs spécifiques. Si ce test s'avère positif, le sujet est alors référé à un spécialiste des maladies génétiques pour un test d'ADN et un suivi médical de sa condition.

\section{Résultats :}

Des activités de formation continue ont été réalisées à travers tout le Québec, rejoignant près de $60 \%$ des optométristes. Après 16 mois d'implantation, ce modèle a permis l'identification de 10 suspects. De ce nombre, 2 patients Fabry ont été diagnostiqués, ce qui a conduit également à l'identification de la maladie chez 5 de leurs proches. Deux autres patients, atteints de Fabry mais sans suivi médical depuis des années, ont été à nouveau pris en charge par le médecin spécialiste. À ce jour, en raison de l'implication des optométristes, 7 nouveaux patients ont donc été dépistés et diagnostiqués alors que 2 reçoivent à nouveau les soins appropriés.

\section{Conclusion :}

En se basant sur les résultats obtenus, le modèle de dépistage mis en place a été évalué comme positif. II confirme le rôle crucial des optométristes dans le dépistage des maladies systémiques ayant des implications oculaires. L'éducation continue est essentielle à la remise à jour et en perspective de notions apprises il y a longtemps mais qui ne se rencontrent pas au quotidien dans les pratiques. De plus, ceci suggère que l'optométriste peut être impliqué dans des équipes multidisciplinaires visant le dépistage de patients à risque et de maladies, notamment celles qui entraînent des manifestations oculaires. 


\section{ABSTRACT}

\section{Purpose:}

Fabry disease is considered a rare disease, based on its prevalence. It is recognized, however, that there are many individuals affected who are unscreened. This article aims to demonstrate how optometrists can help to define improved ways to screen patients affected by this rare metabolic disorder, in a multidisciplinary perspective

\section{Methods:}

A screening model, based on continuous education for optometrists was developed. Under this model, suspect patients identified by optometrists are referred to Université de Montréal's vision clinic (EOUM) for further testing and assessment. Should ocular manifestations and/or case history prove relevant to these rare diseases, a urinary test is then performed to find related biomarkers. When suspicions narrow to probable
Fabry disease, the subjects are referred to metabolic disorder specialists for complete DNA testing and medical follow-up of their condition.

\section{Results:}

Continuous education lectures were given across Quebec, reaching nearly $60 \%$ of the province's optometrists. Sixteen months following the model's implementation, ten suspected patients were referred. Of these, two new Fabry patients were confirmed, leading to the diagnosis of five other relatives with the disease. Two additional persons, diagnosed as Fabry patients, but lost to medical follow-up for many years, were once again placed under the care of Fabry experts. To this point, because of optometric involvement, seven new patients of Fabry were diagnosed and two were brought back under experts care.

\section{Conclusion:}

Continuous education lectures were given across Quebec, reaching near $60 \%$ of the province's optometrists. Sixteen months following the model's implementation, ten suspected patients were referred. Of these, two new Fabry patients were confirmed, leading to the diagnosis of five other relatives with the disease. Two additional persons, diagnosed as Fabry patients, but lost to medical follow-up for many years, were once again placed under the care of Fabry experts. To this point, because of optometric involvement, seven new patients of Fabry were diagnosed and two were brought back under experts care.

Key words: Fabry disease, screening program, corneal pigmentation, urine biomarkers, lysosomal storage disorder diagnosis. On average, this comes 14-16 years following the onset of the first symptoms, ${ }^{5}$ slightly sooner for symptomatic children. For Fabry patients, quality of life, is severely reduced, similar to patients with AIDS 7 . Stress, negative economic repercussions and psychological effects that can lead to moderate to severe depression can affect both patients and their relatives.

Considering the life-threatening aspect of the disease, methods to improve an effective screening of the suspects, at the primary care level, are needed. This becomes essential to target specifically young male patients, more affected, before any major systemic involvement occurs. Because ocular manifestations are among the first to appear in Fabry patients, early in their life, it becomes interesting to consider optometrists as key primary care players to detect and screen for Fabry disease to a greater extent. This article aims to explain how it can be done effectively, in a multidisciplinary perspective.

\section{Fabry disease explained}

Fabry disease is an $\mathrm{X}$-chromosome linked disease, and counts 431 different mutations for the GLA gene.' It is characterized by a deficiency of the lysosomal enzyme alpha-galactosidase A,
(GLA or $a$-gal A) $\cdot{ }^{10}$ Consequently, normal degradation and catabolism processes of membrane glycosphingolipids, namely globotriaosylceramide (also known as GL-3, CTH, or $\mathrm{Gb}_{3}$ ) can no longer be processed in nearly all cells of the human organism. GL-3 substrates cause deposits within the blood vessels. Its distribution is heterogeneous, with a preference for organs that naturally accumulate the greatest amount of it (the heart and kidneys ${ }^{11}$; it also favours the vascular endothelial cells, renal dorsal root ganglion cells, the cornea and the skin ${ }^{12}$. 
Table 1: Signs and symptoms associated with the classic form of Fabry's disease

\begin{tabular}{|c|c|c|}
\hline \multicolumn{2}{|c|}{ Symptoms (most appears in early childhood and adolescence) } & Signs \\
\hline $\begin{array}{l}\text { - Acroparesthesia (numbness, tingling } \\
\text { of the extremities) }\end{array}$ & $\begin{array}{l}\text { - Gastro-intestinal disturbance } \\
\text { or pain }\end{array}$ & $\begin{array}{l}\text { - Angiokeratomas (bathing trunk area, } \\
\text { ombilicus, oral mucosa, fingers, thorax) }\end{array}$ \\
\hline - Joint and abdominal pain & - Altered temperature sensitivity & - Ocular manifestations \\
\hline - Hypohydrosis & - Lethargy & - Facial minor dysmorphic features \\
\hline - Fever & - Cefalea & - Renal dysfunction \\
\hline - Heat/exercice intolerance & - Moderate to severe depression & - Cardiac complications \\
\hline - Hearing loss and vertigo & & - Cerebrovascular disorders (TIA, strokes) \\
\hline
\end{tabular}

During its course, the most severe (referred to as "classic") form of Fabry disease leads to multiple organ damage but clinical presentations typically vary from one patient to another (Table 1). On the other hand, milder or later-onset variants, with manifestations circumscribed to one organ, can be seen in patients showing some residual enzyme activity. ${ }^{13-14}$

In its classic form affecting hemizygotes, the severity of the clinical picture correlates positively with the person's age ${ }^{6}$, but not with genotype - except where vessel tortuosity is present. ${ }^{15-16}$

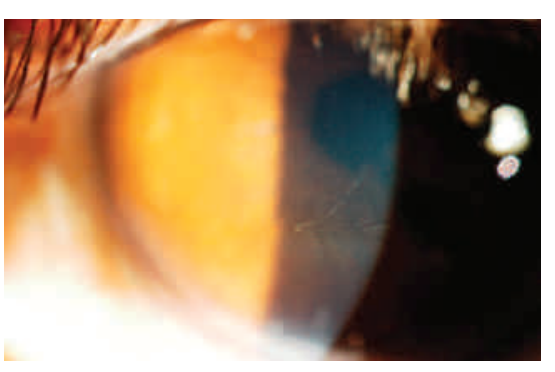

Figure 1-Typical vortex pigmentation of the cornea (verticillata) and corneal haze surrounding the deposits.

\section{Ocular manifestations related to Fabry disease}

Ocular manifestations can be identified very early in childhood, by age three ${ }^{15}$ or even earlier. ${ }^{17}$ These typically occur at the same time as systemic symptoms appear, especially in hemizygous patients.

Classic ocular manifestations include vortex pigmentation of the cornea (verticillata), lens opacities (anterior whitish opacities and posterior subcapsular cataract), conjunctival vessel anomalies (tortuosity and micro-aneurysms) and retinal vessel tortuosities (Figures 1 to 4), ${ }^{15}$ although such manifestations do not usually impair vision but create visual symptoms such as photophobia.

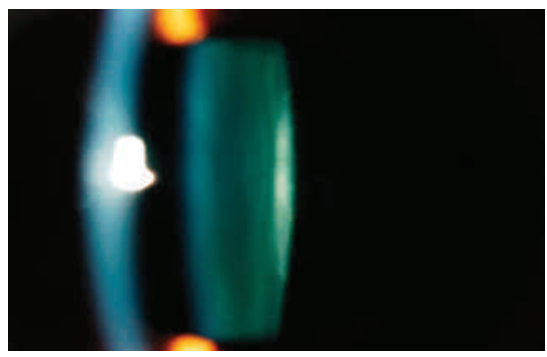

Figure 2-Anterior whitish lens opacities and posterior subcapsular cataract in a 35 year-old Fabry patient.

\section{Systemic treatment}

For decades, therapy was symptomatic. Since 2001 (Europe) and 2003 (USA), enzyme replacement therapy (ERT) has become an available option in the causal treatment, and been shown to be clinically beneficial. ${ }^{18}$ This treatment helps to mitigate signs and symptoms of the disease (Table 2) and would potentially reduce the $\mathrm{Gb}_{3}$ deposition that leads to irreversible organ damage. ${ }^{9,19-20}$ ERT also provides an improvement in quality of life..$^{20}$ In addition to ERT, the most recent pharmacological approach uses genetic therapy or chemicallyinduced pharmacological chaperones 1-deoxygalactonojirimycin (DGJ) and galactose to stabilize the human $a$-GAL glycoprotein and consequently to increase enzyme activity within lyzozomes. ${ }^{21}$

Without treatment, male Fabry patients usually die 20 years earlier than the general male population, due to renal failure, progressive cardiomyopathy and/or cerebrovascular events. ${ }^{22}$ Women also have a shorter life expectancy of 15 years compared with the general population. ${ }^{22}$ 
One way to reverse this natural course is to implement efficient screening strategies to identify suspects early in the disease process, and to refer them to Fabry specialists in a timely manner. Such a screening strategy can start with the involvement of those who see these potential patients on a daily basis. Considering that ocular manifestations are among the first to appear and the easiest to assess, ${ }^{23}$ eye care professionals should be targeted as key players. $^{16}$

\section{Methods}

\section{Defining the model}

In 2009, a collaborative pattern for the ocular follow-up of diagnosed Fabry patients, under the requirements of the Canadian Fabry Disease Initiative, was established between Université de Montréal, École d'optométrie (EOUM), and the genetic center of one of its university hospital (Hôpital du Sacré-Cœur de Montréal), treating most of the Fabry patients in the province. The first step in responding to CFDI's request

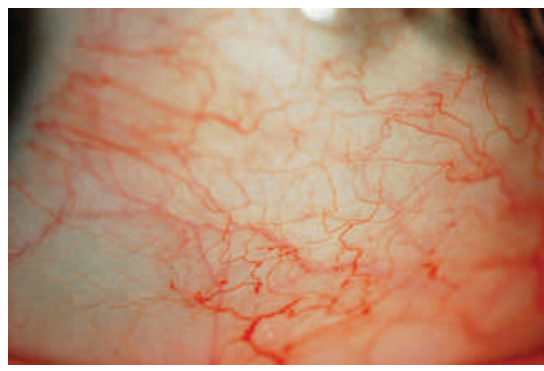

Figure 3-Tortuosity and micro-aneurysms of blood vessels as they can be seen in the conjunctiva of a 42 year-old female patient.

was to review their requirements for oculo-visual examination and follow-up (time, equipment, standards, etc.) Secondly, a faculty member (LM) from EOUM was designated to take charge of the project, based on expertise in anterior segment. The third step was to secure a formal referral pathway that would function reciprocally between EOUM and the CFDI research team (under Dr. Bichet, of Hôpital du Sacré-Cœur de Montréal). The fourth step was then developed. It involved recruiting practising optometrists to screen for Fabry patients on a large scale. Several continuing education lectures were conducted across

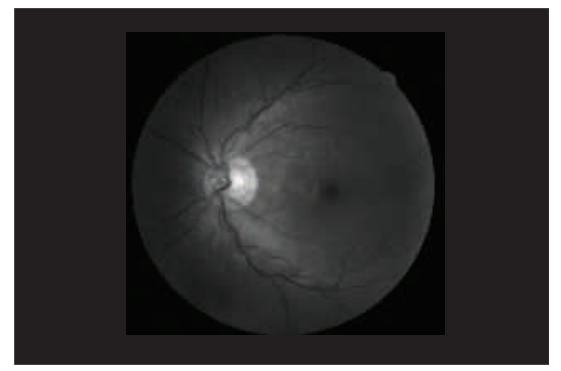

Figure 4-Retinal vessel tortuosities, best seen in red-free photograph, in an 18 year-old Fabry patient.

the province. During these. events, emphasis was made on the clinical course of the disease (age of onset and natural evolution), the systemic symptoms and ocular manifestations related to Fabry and the proposed screening referral pathway. Written documentation (manuscripts, posters with photos) and DVDs about Fabry and other lysosomal storage disorders were also provided as reminders for in-office use.

Under the developed model, a patient presenting with specific ocular manifestations and/or symptoms of Fabry is considered a suspect. The situation is explained to the patient who is offered to be

Table 2: Summary of the effects of enzyme replacement therapy (ERT) on Fabry's patients

\begin{tabular}{|l|l|}
\hline \multicolumn{1}{|c|}{ Symptoms } & \multicolumn{1}{c|}{ ERT outcome } \\
\hline $\begin{array}{l}\text { - Gastrointestinal disturbance /abdominal pain } \\
\text { - Renal function (overall) }\end{array}$ & $\begin{array}{l}\text { - Alleviated } \\
\text { - Proteinuria }\end{array}$ \\
$\begin{array}{ll}\text { - Cardiac complications } \\
\text { - Hearing }\end{array}$ & $\begin{array}{l}\text { - Not improved } \\
\text { - Cerebrovascular events }\end{array}$ \\
& $\begin{array}{l}\text { (if hypertrophy present before tx) } \\
\text { - Stabilize or improve (enzyme alpha) }\end{array}$ \\
\hline
\end{tabular}


seen at EOUM's vision clinic for confirmation and further assessment. If the clinical findings prove relevant (presence of corneal pigmentation and at least manifestation of one systemic symptom), or in the case of a positive genetic background, a urine sample collected on filter paper is sent to the CHUS Expertise Centre in Clinical Mass Spectrometry (Dr. Auray-Blais Waters' laboratory) for tandem mass spectrometry analysis for $\mathrm{Gb}_{3}$ levels (see below). In the case of patients living outside of Montreal area, urinary test kits (filter papers and request forms) are sent to local optometrists to be administrated. Based on clinical and lab results, if enough suspicion points to Fabry (cornea verticillata, systemic symptoms and positive urinary test result for $\mathrm{Gb}_{3}$ accumulation), a referral is made to the nearest genetic centre for complete DNA testing and follow-up.
Ocular data collected from confirmed patients are part of the CFDI registry and constitute the basis of our current longitudinal study on ocular manifestations related to Fabry.

\section{Urinary biomarker testing}

A method for screening high-risk individuals was developed to detect both male and female Fabry disease patients. ${ }^{24}$ The methodology is reliable, efficient and specific, if done after the age of 6 years. It is based on an analysis of urinary $\mathrm{Gb}_{3}$ using tandem mass spectrometry, ${ }^{25-26}$ in a laboratory in Sherbrooke, QC. Urinary excretion of $\mathrm{Gb}_{3}$ is normalized to creatinine $e^{27}$ and patients are always age-matched to controls. ${ }^{28}$ Nevertheless, it must be taken into account that patients with cardiac variant mutations who have residual enzyme activity do not excrete excessive amounts of $\mathrm{Gb}_{3}$ in their urine.

\section{Results}

\section{Continuous education}

During the first 16 months of the project, 750 Quebec optometrists (out of 1,300-57.6\%) participated in continuing education events, during evening and weekends.

\section{Patient referrals}

The first examination of a patient referred to the EOUM clinic was made in September 2009. Since that time, 10 patients have been seen, (Table 3), referred by optometrists who attended continuing education events.

The urinary test was performed on every suspect (6 out of 10) who showed signs (3 suspects) or symptoms (3 suspects) that suggested Fabry. This test

Table 3 : Demographics of the referred patients to $U$ de $M$ vision clinic for screening

\begin{tabular}{|c|c|c|c|c|c|c|c|}
\hline $\begin{array}{l}\text { Patient } \\
\text { Sent } \\
\text { by ODs }\end{array}$ & Sex & Age & $\begin{array}{l}\text { Corneal } \\
\text { pigmentation } \\
\text { seen }\end{array}$ & $\begin{array}{l}\text { Positive Case } \\
\text { History (Systemic } \\
\text { symptoms) }\end{array}$ & $\begin{array}{l}\text { Urinary } \\
\text { test } \\
\text { ordered }\end{array}$ & $\begin{array}{l}\text { Patient sent } \\
\text { for DNA } \\
\text { testing }\end{array}$ & $\begin{array}{l}\text { Fabry's } \\
\text { confirmed }\end{array}$ \\
\hline 1 & $F$ & 18 & Yes-typical* & Yes & Yes & Yes & Yes \\
\hline 2 & M & 22 & Yes (1) & No & No & No & No \\
\hline 3 & $F$ & 34 & No & Yes & Yes & No & No \\
\hline 4 & $\mathrm{~F}$ & 51 & No & Yes & Yes & No & No \\
\hline 5 & M & 39 & No & Yes & Yes & No & No \\
\hline 6 & $M$ & 23 & Yes-typical & Yes & Yes & Yes & Yes \\
\hline 7 & $F$ & 62 & Yes (2) & No & No & No & No \\
\hline 8 & $\mathrm{~F}$ & 51 & Yes-atypical & Yes(a) & Yes & Yes & No \\
\hline 9 & M & 46 & Yes (3) & No & No & No & No \\
\hline 10 & $\mathrm{~F}$ & 35 & Yes (4) & No & No & No & No \\
\hline
\end{tabular}

- Typical means bilateral pigmentation, verticilatta type, asymetrical

- Hudson-Stahli type of pigmentation- monocularNot related to Fabry

- Pigmentation secondary to amiodarone symetrical OU

- Pigmentation secondary to chloroquine

- Pigmentation secondary to scarring

- Relatives affected (cousins) 
allowed for the detection of 2 out of 3 suspects who showed corneal pigmentations and symptoms. The discovery of these patients led to cascade screening and the detection of other Fabry patients (5) in the family, including two young homozygous patients five and seven years old, respectively. The last patient with corneal signs had a negative result on the urinary test. However, because of her positive family background for the disease (cousins were known Fabry patients), she was referred for DNA testing which was also negative.

In addition to these patients, four additional suspects living in rural areas were co-managed with their local optometrists. Urinary tests were negative for the disease and consequently they were not referred for DNA testing.

Aside from these 19 individuals (10 suspects seen +5 relatives +4 co-managed patients), two other patients who had been lost to follow-up for many years were brought back under the care of either Dr. Bichet's team or a local geneticist in Quebec City, following an optometric examination.

In total, 7 new patients $(2+5$ relatives) were diagnosed as a direct consequence of the screening model we have established, and 2 more were brought back under appropriate care for their systemic condition.

\section{Discussion}

In the past, several strategies have been proposed to increase screening for patients with rare diseases. ${ }^{29}$ These strategies have included developing and launching an interactive public website to inform and communicate with the public and with medical professionals; a mail-based survey of all primary care physicians of a known area; systematic targeted screening of the relatives of patients already diagnosed, and a newborn/population-based urine testing program should biomarkers be detected. For Fabry disease in particular, very few other initiatives have been implemented worldwide to increase the screening rate for patients. Some initiatives have attempted to look at specific groups of patients considered to be "at risk" based on their signs or symptoms. For example, studies have been conducted among hemodialysis patients, with a positive-identification success rate of 0.2 to $1.2 \% .^{30}$ A similar approach involving patients presenting with cryptogenic stroke or unexplained left ventricular hypertrophy have yielded a 3-6\% success rate. ${ }^{31}$

In Argentina, blood sampled on filter paper (dry blood testing) from patients with signs and symptoms has been systematically sent for analysis, with a yield of detection of $4.96 \%$. Using this approach, 70 patients were found positive for the disease within 2.5 years of implementation of the protocol. ${ }^{32}$ One other experiment was conducted in Germany in 2003: 615 ophthalmologists were recruited and 125,908 patients were examined. Out of these, 44 subjects $(3.5 \%)$ were suspects and $21(1.75 \%)$ were confirmed as Fabry patients. This result was not considered as successful as other strategies, due to the time and effort needed to screen a small number of patients. ${ }^{33}$

As mentioned previously, in order to increase the overall positive results from screening strategies, it is preferable to develop a targeted protocol and to constitute an interdisciplinary group to identify confirmed patients. In our case, several aspects of other screening programs were put into place with the uniqueness to include optometry in the multidisciplinary team and to be able to rely on biomarker testing at an affordable cost, compared to the higher cost of DNA testing. Referral patterns were set up considering available resources.

The innovative feature of our approach was to involve optometrists, on a large scale, as team members for the screening effort. In North America, optometrists represent the most accessible resources in primary eye care. In the province of Quebec specifically, 1,300 optometrists see $30-35 \%$ of the population every year. ${ }^{34}$ This high level of population penetration represents a unique opportunity for screening a large population for Fabry disease. 


\section{Limitations of our analysis}

We cannot estimate our rate of success as defined by the percentage of patients screened based on the total number of patients who consulted an optometrist who attended a continuing education event. We cannot estimate the male/female ratio of patients who consulted with a trained optometrist during this 16 months period of time. It is therefore difficult to compare our data with the German experiment or other screening projects.

On the other hand we can roughly approximate the value of the model. Since we know that those who attended continuing education. events represent $60 \%$ of Quebec optometrists, we can assume that they have seen as many as 2.4 million people, in theory, over the last 16 months (3 million/ year/total ODs x $60 \% \times 1.33$ years). Considering that the prevalence of Fabry is $1 / 200,000$ in the general population we can estimate that 12 Fabry patients $(2.4$ million $\times 1 / 200,000)$ should have been seen. The screening process helped to identify 7 individuals who were not diagnosed, priorly, and 2 that were lost to follow-up. In such a perspective, 9 of 12 potential patients were identified. This gives an idea of the value of the screening effort.

On the other hand, most of the patients referred to EOUM for confirmation of the disease were not found positive for Fabry, based on the lack of symptoms or due to other corneal pigmentation causes. This suggests that the educational process can be improved, or repeated. Also, sensitivity of the screening could be improved by modifying the referral criterion to only include patients with corneal deposits (unexplained by other commonly known drugs or other common causes of corneal pigmentation) and the presence of systemic symptoms or a family history.

\section{Updated Data}

The continuous education seminars were also conducted across Canada. As of December 2012, 18 other patients and relatives were found by optometrists and confirmed as Fabry patients. This brings the total of patient screened up to 25 in the last 2.5 years.

\section{Conclusion}

Overall, a year and a half after its implementation, this screening program met its goals, as it involved optometry and helped uncover new Fabry patients in Quebec.

This screening program was effective because it was based on a defined protocol, a multidisciplinary approach and a major effort to provide up-to-date information to optometrists as primary care providers.

Our ability to rely on an accessible resource, everywhere in the territory, helped immeasurably. In this sense, optometrists should be considered key players in the development of any large-scale screening program for rare diseases involving ocular manifestations.

\section{References}

1. Meikle PJ, Hopwood JJ, Clague AE, Carey WF. Prevalence of lysosomal storage disorders. JAMA 1999; 281: 249-54.

2. Spada M, Pagliardini S, Yasuda M, Tukel T, Thiagarajan G, Sakuraba H, Ponzone A, Desnick RJ. High incidence of later-onset Fabry disease revealed by newborn screening. Am J Hum Genet. 2006 Jul;79(1):31-40.

3. Hoffmann B, Mayatepek E. Fabry disease - often seen, rarely diagnosed. Dtsch Arztebl Intl. 2009; Jun, 106(26): 440-7.

4. Rozenfeld PA. Fabry disease: Treatment and diagnosis. IUMB Life 2009; 61(11): 1043-50.

5. Mehta A, Ricci R, Widmer U, Dehout F, Garcia de Lorenzo A, Kampmann C, Linhart A, Sunder-Plassmann G, Ries M, Beck M. Fabry disease defined: baseline clinical manifestations of 366 patients in the Fabry Outcome Survey. Eur J Clin Invest. 2004; 34: 838-44.

6. Ramaswani U, Whybra C, Parini R Pintos-Morell G, Mehta A, SunderPlassmann G, Widmer U, Beck M; FOS European Investigators. Clinical manifestations of Fabry disease in children: data from the Fabry Outcome Study. Acta Paediatr. 2006; 95: 86-92.

7. Gold KF, Pastores GM, Botteman MF, Yeh JM, Sweeney S, Aliski W, Pashos CL. Quality of life of patients with Fabry disease. Qual Life Res. 2002 Jun;11(4):317-27.

8. Cole AL, Lee PJ, Hughes DA, Deegan PB, Waldek S, Lachmann RH. Depression in adults with Fabry disease: a common and under-diagnosed problem.J Inherit Metab Dis. 2007 Nov;30(6):943-51.

9. Motabar O, Sidransky E, Goldin E, Zheng W. Fabry disease - current treatment and new drug development. Curr Chem Genomics 2010; 4:50-56. 
10. Desnick RJ, Iaconnu YA, Eng C. a-galactosidase A deficiency: Fabry disease. In The Metabolic and Molecular Bases of Inherited Disease (Scriver CR, Beaudet AL, Sly WX and Valle D, eds). New York, McGraw Hill, 1995, pp 2741-84.

11. Askari H. Kaneski C. Semino-Mora C, Desai P, Ang A, Kleiner DE, Perlee LT, Quezado M, Spollen LE, Wustman BA, Schiffmann R. Cellular and tissue localization of globotriaosylceramide in Fabry disease. Virchows Arch.

12. Tavakoli M, Marshall A, Thompson L, Kenny, M, Waldek S, Efron N, Malik RA. Corneal confocal microscopy: a novel noninvasive means to diagnose neuropathy in patients with Fabry disease. Muscle nerve 2009; Dec; 40(6): 976-84.

13. Nakao S, Takenaka T, Maeda M, Kodama C Tanaka A, Tahara M, Yoshida A, Kuriyama M, Hayashibe $\mathrm{H}$, Sakuraba H. An atypical variant of Fabry's disease in men with left ventricular hypertrophy. N Engl J Med 1995; 333: 288-93.

14. Nagao Y, Nakashima H, Fukuhara Y, Shimmoto M, Oshima A, Ikari Y, Mori Y, Sakuraba H, Suzuki Y. Hypertrophic cardiomyopathy in late-onset variant of Fabry disease with high residual activity of alpha-galactosidase A. Clin Genet 1991; 39: 233-37.

15. Sodi A, Ioannidis AS, Mehta A, Davey C, Beck M, Pitz S.Ocular manifestations of Fabry's disease: data from the Fabry Outcome Survey. Br J. Ophthalmol. 2007; 91: 210-14.

16. Allen LE, Cosgrave EM, Kersey JP, Ramaswani U. Fabry disease in children: correlation between ocular manifestations, genotype and systemic clinical severity. Br J Ophthalmol. 2010; 94: 1602-05.

17. Tsutsumi A, Uchida Y, Konai T. Corneal findings in a fœtus with Fabry's disease. Acta Ophthalmol (Copenh). 1984, 62: 923-31.

18. Eng CM, Guffon N, WIlcox WR, Germain DP, Lee P, Waldek S, Caplan L, Linthorst GE, Desnick RJ; International Collaborative Fabry Disease Study Group. Safety and efficacy of recombinant human alpha-galactosidase
A- replacement therapy in Fabry's disease. N Engl J Med. 2001; 345: 9-16.

19. Lee K, Jin X, Zhang K, Copertino L, Andrews L, Baker-Malcolm J, Geagan

L, Qiu H, Seiger K, Barngrover

D, McPherson JM, Edmunds T. A

biochemical and pharmacological comparison of enzyme replacement therapies for the glycolipid storage disorder Fabry disease. Glycobiology 2003; 13: 305-13.

20. Hoffmann B, Beck M, SudnerPlassmann G, Borsini W Ricci R, Mehta A; FOS European Investigators. Nature and prevalence of apin in Fabry disease and its response to enzyme replacement therapy - a retrospective analysis from the Fabry otucome study. Clin J Pain 2007; 23: 535-42.

21.Rozenfeld P, Neumann PM. Treatment of Fabry disease: current and emergent strategies. Curr Pharm Biothechnol. 2011; 12(6): 916-22.

22. MacDermot KD, Holmes A, Miners AH. Anderson-Fabry disease: clinical manifestations and impact of disease in a cohort of 98 hemizygous males. J M'ed Genet 2001;38:750-60.

23. Sodi A, Ioannidis AS, Meltha A. Ophthalmological manifestations of Fabry disease. In: Methe A, Beck M, Sudner-Plassmann G. eds. Fabry disease. Perspectives from 5 years of FOS. Oxford UK: Oxford Pharmagenesis Ltd, 2006: 249-61.

24. Auray-Blais C, Clarke JTR, Young SP, Millington DS, Schiffmann R. Proposed high-risk screening protocol for Fabry disease in patients with renal and vascular disease, J. Inherit. Metab. Dis. 2009; 32(2) 303-308.

25. Auray-Blais C, Cyr D, Ntwari A, West ML, Cox-Brinkman J, Bichet DG, Germain DP, Laframboise R, Melançon SB, Stockley T, Clarke JTR, Drouin R. Urinary globotriaosylceramide excretion correlates with the genotype in children and adults with Fabry disease. Mol. Genet. Metab. 2008; 93(3): 331-340.

26.Auray-Blais C, Cyr D, Mills K, Giguère R, Drouin R. Development of a filter paper method potentially applicable to mass and high-risk urinary screenings for Fabry disease. J. Inherit. Metab. Dis. 2007; 30(1): 106.
27. Auray-Blais C, Millington DS, Barr C, Young SP, Mills K, Clarke JTR. Gb3/ creatinine biomarkers for Fabry disease: Issues to consider. Mol. Genet. Metab. 2009; 97, 237

28. Barr C, Clarke JTR, Ntwari A, Drouin R, Auray-Blais C. Fabry disease urinary globotriaosylceramide/ creatinine biomarker evaluation by liquid chromatography-tandem mass spectrometry in healthy infants from birth to 6 months. Mol. Genet. Metab. 2009; 97, 278-283.

29. Ranganath L, Taylor AM, Shenkin A, Fraser WD, Jarvis J, Gallagher JA, Sireau $\mathrm{N}$. Identification of alkaptonuria in the general population: a United Kingdom experience describing the challenges, possible solutions and persistent barriers. J Inherit Metab Dis. Published online (http://www.springerlink.com/content/ m1j1w2612h8471p1/) Feb 2011

30. Kotanko P, Kramar R, Devrnja D, Paschke E, Voigtländer T, Auinger M, Pagliardini S, Spada M, Demmelbauer K, Lorenz M, Hauser AC, Kofler HJ, Lhotta K, Neyer U, Pronai W, Wallner M, Wieser C, Wiesholzer M, Zodl H, Födinger M, Sunder-Plassmann G. Results of a nationwide screening for Anderson-Fabry disease among dialysis patients. J Am Soc Nephr 2004; 15: 1323-29.

31. Sachdev B, Takenaka T, Teraguchi $H$, Tej C, Lee P, McKenna WJ, Elliott PM. Prevalence of Anderson-Fabry disease in male patients with late onset hypertrophic cardiomyopathy. Circulation 2002; 105: 1407-11.

32. Rozenfeld PA, Tarabuso A, Ebner R, Ramallo G, Fossati CA. A successful approach for the detection of Fabry patients in Argentina. Clin Genet 2006; 69: 344-48.

33. Houser AC, Lorenz M, Voigtlander T, Födinger M, Sunder-Plassmann G. Results of an ophthalmologic screening programme for identification of cases with Anderson-Fabry disease. Ophthalmologica 2004; 218: 207-9.

34. Association des Optométristes du Québec, Montréal, Québec. Statistics on file. 